\title{
The making and remaking of ecological space in China: the political ecology of Chongming Eco-Island
}

Linjun Xie*, University of Nottingham Ningbo

Andrew Flynn, Cardiff University

May Tan-Mullins, University of Nottingham Ningbo

Ali Cheshmehzangi, University of Nottingham Ningbo

\begin{abstract}
This paper contributes to debates on urban sustainable development through a critical examination of current state-led and Ecological Modernization-guided eco-developments in China. Using Chongming Eco-Island as a case study, we critically evaluate the practices and effects of current Chinese eco-development alongside ecological, economic, and social dimensions. Adopting an alternative analytical approach - political ecology, our analysis brings to the fore a host of stakeholders' voices and knowledge (especially the often-marginalized grassroots), triangulated with archival research and on-site observation. Our findings show that the EcoIsland development with an Ecological Modernization bias generates unintended and adverse results for the local community and the environment. We argue that political ecology, as both a contesting perspective in sustainable development and as a critical analytical method in understanding society-environment relations, serves as an attractive alternative strategy for those seeking to analyze a more nature-focused, locally-relevant means to promote just planning for urban sustainability.
\end{abstract}

Keywords: Political ecology; Ecological modernization; Eco-development; Urban sustainability; Chongming Eco-Island

\section{Introduction}

The $17^{\text {th }}$ National Congress of the Communist Party of China (CPC) (2007) proposed the idea of Ecological Civilization (EC) as a national goal. For the first time, eco-civilization had been written into the CPC's National Congress report, showing the country's commitment to environmental improvement and sustainable development. The decision of the CPC had followed that of the influential China Modernization Report 2007: Study on Ecological Modernization published by the Chinese Academy of Sciences (CAS). This 450-page report marks the official articulation of Ecological Modernization (EM) theory in China (China Centre for Modernization Research, 2007). Since then, China has been vigorously implementing EC across the country, and EM is the dominant guiding development theory and approach. The original term "Ecological Civilization" is even deemed as a synonym for "EM with Chinese characteristics" (Muldavin, 2015: 1000). 
Ecological Modernization has strong European roots. The theory of EM emerged from debates on capitalism, sustainability, and the state dating back to the 1980s. Unlike the neo-Marxists' view on capitalism which sees it as a fundamentally unsustainable regime due to its drive for endless growth, profit maximization, and capital accumulation, EM advocates argue that the processes of modernization and capitalization can be compatible with environmental priorities (Zhou, 2015). Therefore, underlying the principle of EM, is a firm belief that economic and environmental objectives are complementary (Fisher and Freudenburg, 2001, Keil and Desfor, 2003, Krueger and Gibbs, 2007, Mol et al., 2009). With this guiding logic, the paradigm of EM places emphasis on reconciling and mutually enhancing economy and ecology relations, namely finding productive uses for natural resources and ecosystems as these are the basis of both current and future growth and development (de jong et al, 2015). Since the turn of the century EM has increasingly shaped urban policy and practice (Mol, 2001; Mol et al. 2009).

EM is an optimistic, pragmatic, and policy oriented theoretical framework. For its proponents, EM provides insights into effective practices in a variety of social and economic contexts that can promote more environmentally informed policy changes (Zhou, 2015). China, as a developing country that is undergoing transition from a planned to market economy is having to cope with alarming environmental degradation while continuing to pursue rapid development and growth. Perhaps, not surprisingly, with its promise of being able to reconcile economic and environmental goals, EM thinking has been widely embraced in China. There are, though, significant differences between Western and Chinese versions of EM. As shown in the CAS's 2007 report and many subsequent governmental documents, Chinese interpretations of EM are primarily limited to the technological-economic dimensions of sustainable development, assuming a 'win-win' achievement of economic development and environmental clean-up (Zhang et al, 2007; Muldavin, 2015). The wider governance innovations, that include roles for pressure groups and more inclusive decision making, that are integral to Western perspectives on EM, are outside of the scope of the Chinese version (Zhang et al, 2007).

With more research on Chinese eco-developments there is ever growing evidence that Chinese eco-initiatives align with a Chinese model of EM (see Hult, 2013, Joss et al., 2013, Neo and Pow, 2015, Rapoport and Hult, 2017). As commentators have pointed out eco-developments emphasize the capability of economic advance and technological fixes in addressing environmental challenges, but in doing so adopt an overly anthropocentric version of the environment and marginalize social well-being (de Jong et al., 2013; Yu, 2014; Hult, 2015; Pow and Neo, 2013). Consequently, the Chinese version of EM is characterized as a weak form of EM that adopts a corporate, technocratic solution to environmental problems (Christoff, 1996) ${ }^{1}$, and for its critics is particularly problematic (Muldavin, 2015).

Key weaknesses in the Chinese approach to EM, include limited civil society participation and a negligible concern for social sustainability (Muldavin, 2015; Zhang et al, 2007). Whilst China's strong state and the top-down policy-making style may be more amenable to efforts to materialize eco-developments and to produce faster changes (Zhou, 2015; Neo and Pow, 2015),

\footnotetext{
1 In contrast, a "strong" EM should address the economical, systematic, communicative, deliberative, democratic, and international dimensions of environmental institutions (Christoff, 1996).
} 
there is little room, if any, for public engagement. Therefore, in official Chinese EM discourses, there has been little if any discussion of equity, equality, citizen empowerment and the like. Consequently, EM may limit understanding of (and available solutions) to China's environmental problems (Muldavin, 2013). At present, it remains largely unexplored as to what might be the local effects of current China's EM-led eco-developments. Moreover, there is also the scope for research that explores the potential alternatives for more ecologically informed and socially sustainable approaches to eco-developments.

This paper seeks to remedy these gaps in knowledge by providing an up-to-date theoretically informed and critical on-the-ground assessment of eco-development in China. The paper demonstrates the limitations of the EM approach to eco-development by counterposing them with a political ecology perspective. We show how a political ecology framing of ecodevelopment help us to understand the nature of the responses of a community that is subject to an eco-development. By drawing on grassroots voices we provide novel insights into how communities perceive their environment and the changes that it is experiencing. We do this by dissecting the practices and implications of the high-profile Chongming Eco-Island in Shanghai. We support Muldavin's (2013) argument that Political Ecology, a theory that is generally concerned with the relations between social and environmental conditions and uneven power relations (see Brown and Purcell, 2005, Bryant and Bailey, 1997, Bryant, 1998, Keil, 2003, Robbins, 2012), is a fruitful perspective for research and for development. The reasons are three-fold. Firstly, as political ecology probes the "restructuring" of social and environmental relations at multiple scales during policy changes, and reveals the dynamics of unequal power, territories/spaces, and nature/resources, it offers insights for our understanding of the nature of contemporary governance of ecological development in China (Muldavin, 2013; Harris, 2017). Secondly, political ecology harbors an ethnographic component and privileges the rights and concerns of marginalized groups and a marginalized environment by challenging mainstream environmental management approaches that are commonly dominated by powerful political and economic elites (Bryant, 2004). Meanwhile, as a "vociferous critic of all forms of capitalism" (Neo and Pow, 2015: 406), a political ecology framework provides a critical examination and welcome antidote to current pro-growth and EM-led eco-developments in China. Therefore, political ecology helps to both critically examine the socio-economic and environmental outcomes of current Chinese eco-developments and identify ways of thinking and working differently around sustainability. Third as political ecologists are urged to work to better understand state institutions (Robbins, 2003), Yeh (2015) has specifically argued that to enrich political ecology scholarship of China, there is a need for detailed local analyses to uncover the mosaic of humanenvironment relations. This study contributes to these tasks with our study on the challenges of promoting a more ecologically friendly and socially just form of development on Chongming EcoIsland (see below).

The remainder of the paper is divided into four sections. The following Section begins with a discussion of distinctive Chinese eco-development conditions, before analyzing the links between political ecology and eco-development in China. Following this, Section three presents a justification for using Chongming Eco-Island as a case study and elaborates on the research methodology employed. In Section four, the planning and implementation of Chongming Eco- 
Island are examined from a political ecology view, in terms of environmental, economic and social effects. As we point out, Chongming Eco-Island's planning and strategies are regularly revised and thus help to reveal the features and effects of Chinese state-led and ecologicalmodernization guided eco-development. We are thus also able to reflect on the implications of political ecology as a theoretical framework and counter narrative for sustainable development. This also contributes to the broader understanding of urban sustainable development debates in China.

\section{Political ecology of eco-developments in China}

Whilst critiques of Chinese eco-developments become increasingly evident (see Joss and Molella, 2013, Neo and Pow, 2015, Yu, 2012, Yu, 2014), details of the implementation and effects of ecoprojects in China remain underexplored. How is the state driving eco-development through the contents of policies and plans? What form do eco-developments take on the ground? How do policy makers and communities respond to changes that have been produced regarding environmental, economic and social issues? More specifically, how are local communities and residents affected in terms of their socio-economic conditions? Is a more sustainable trajectory emerging? In seeking to answer these questions, more radical concepts providing contesting views of urban-nature relationships at odds with EM ideals emerged (Keil, 2003, Swyngedouw, 1997). A popular alternative perspective is political ecology, which unequivocally resists both capitalism and associated modernization thinking (Muldavin, 2013, Yeh, 2009). For its advocates, political ecology is a productive approach that usefully picks up issues that an EM framework fails

to adderess in eco-developments, such as the distribution of costs and benefits between the environment and development and between generations, and the intensification of social injustice (Yeh, 2009). Since these social-economic and environmental challenges and problems are also shown to be present in the majority of Chinese eco-developments (e.g. Caprotti, 2014a, Caprotti, 2014b, Caprotti et al., 2015, Grydehøj and Kelman, 2016, Hodson and Marvin, 2010), it is important that they are investigated. Moreover, within a system of authoritarian environmental governance (Tan-Mullins et al., 2017a; Tilt, 2007), grassroots voices are rarely listened to and are all too easily ignored. Political ecology focuses on communities' perceptions of their environment, how that is changing and the opportunities that they have to voice their views. We are thus able to provide an analysis of what communities' value in their environment and how that may differ from the perspective of officials who seek to manage a locality from a distance. In this way, we can draw out competing and contested perspectives of the environment and of eco-development.

Within the literature on political ecology there are a set of key themes that are relevant for our analysis of Chongming Eco-Island. Firstly, rooted in the political ecology concept is the assertion that environmental issues are not solely a subject of natural science, but are inherently associated with political, economic and social actions, and more precisely, with questions about place and power (Bryant, 1998). Often, the power of different actors is conceptualized by their ability to control access to valued environmental resources and the economic benefits ensuing from resource exploitation (see Bryant and Bailey, 1997, Tan-Mullins et al., 2017b). As stakeholders are variably empowered by different resources such as knowledge and technology 
as well as access to information (Tan-Mullins et al., 2017b), they gain uneven power to effect change on the environment. Stakeholders may also have distinct perceptions of natural resources (Bryant and Bailey, 1997, Hung and Sheu, 2010, Neumann, 2005, Peet et al., 2011, Robbins, 2012). As we shall see in our case study below local actors perceive their environment in a different way to external planners.

A second theme, also at the heart of political ecology, is the notion of the environment. While EC and narrow views of EM begin to find ways to internalize the environment into everyday actions and practices, they are essentially anthropocentric. For both EM and Chinese eco-development policy there is a narrow view of the environment and what it means for local people; environment becomes part of an anthropocentric perspective that is seeking win-win outcomes. For political ecologists, though, local people have a more intuitive, eco-centric perspective which rejects or at least does not connect with such a rationality. There does, though, need to be some caution in not prematurely closing off an important topic for study by assuming that local, rural people, in particular, will have a more eco-centric approach to nature. Attention also needs to be given to the ways in which local actors' perspectives on nature may be shaped and reshaped by their engagement with wider debates on eco-development.

In a third and related theme, political ecology has focused on rural areas and been interested in local people and their views on nature (Leff 2015, 71). Studies have examined food and farming, water resources, forests and minerals (Barca and Bridge 2015, 370) and sought to explore how marginal groups - peasants, indigenous people, women, ethnic and religious minorities - have resisted both their and their land's exploitation (Perrault et al 2015, 8). Our study adds to the literature on political ecology because a) we draw to the fore political structures and processes that shape local environmental change and provoke resistance, and b) explore transformations in understandings and practices relating to the environment. This is particularly important, as in our analysis of Chongming Eco-Island, development is promoted as a way of enhancing the environment rather than the more typical case of exploiting it.

A fourth theme relates to the inclusion of a host of stakeholders and actors (especially those marginalized groups) drawn into a political ecology perspective (Bryant and Bailey, 1997, Robbins and Sharp, 2003, Swyngedouw, 2004, Yeh, 2009). This results in more comprehensive efforts to disentangle socio-political, economic, and ecological dynamics in explaining eco-developments. Opening up alternative perspectives on eco-development enables the identification of areas where there is contestation over environmental features (e.g. river management) and where actors' views may complement or support one another. In our approach, we analyze why state actors, principally land use planners, adopt a more ecologically modern perspective on development and their understanding of the environment. It is in the spaces between political authority and local priorities that there is the potential for local forms of resistance to imposed environmental change.

A fifth theme relates to debates on the distinctive governance setting of China (Horowitz, 2015) because of its state authoritarianism. This is highlighted in debates surrounding the extent to which the Chinese state may be able to accommodate civil society groups (Horowitz, 2015) and 
of the nature of environmental protest. While environmental protest can take many forms, from demonstrations to petitions and cover a variety of issues such as land reform or air quality, there is no indication that it may become a way to challenge the authority of the state, as has happened in Thailand (Forsyth, 2004). Indeed, more typical protest is subtle and takes the form of persistent persuasion (Lang and Xu, 2013). As Horowitz (2015) has argued research needs to pay much closer attention to the ways in which governance shapes opportunities for protest. By following this line of thinking we argue that people on Chongming are not passive but recognize the limits in which protest can take place. Moreover, as we shall see although there were persistent claims about how the environment was being degraded protest on Chongming does not fall within the environmental movement category (Horowitz 2015, 247-8) because it is largely informal and ad hoc and individual rather than collective behavior is to the fore. Moreover, protestors did not seek to rescale activities by linking to other or networks in nearby Shanghai or beyond. This was a set of concerns voiced by and for Chongming Eco-Islanders to those who governed them. By further developing the political ecology perspective to more fully appreciate the governance context we examine how in conditions of highly unequal power relations, ecologically informed oppositional ideas persist.

In the Chinese case, it is important to recognize the state's disproportionate and overwhelming influence in environmental interventions, and that these may often lead to unintended and even pernicious socio-environmental results (Bryant and Bailey, 1997, Neumann, 2005, Peet et al., 2011, Robbins, 2012) (again as we shall see in our case study with the canalization of a river). As most eco-developments in China are initiated and implemented by governments at multi-levels in cooperation with other state actors (such as state-owned enterprises), non-state actors' voices are often muted (or absent) during the policy-making process (Flynn et al, 2016; Caprotti and Gong, 2017). We, therefore, take the planning and development process as our starting point, since these shape development possibilities and opportunities for citizen engagement. Our case study of Chongming Island is part of the Shanghai metropolitan area but can appear both physically removed because of the traditionally poor communication links and economically detached as it is a rural space within a very large urban-industrial complex. This matters for how the Island is conceptualized - it is somewhere else - and for how planning takes place Chongming County Government (which has been upgraded to Chongming District Government since 2016 (Shanghai Municipal Government, 2016a)) like other county governments in China works within a strict hierarchy but its rurality (and thus backwardness in relation to widespread perceptions of a modern megacity) means that its views carry even less weight. So, political ecology opens up opportunities for our research on opaque actors in eco-developments such as farmers to yield more understanding of the operation of power and discourse in practice, and to further reveal governing logics and state power.

To summarize our position, we need to recognize the distinctive ways in which many environmental, political and societal debates play out in China and how these may contribute to a vibrant political ecology research agenda. Although there are many points that could be raised to highlight the distinctiveness of political ecology in China, more specifically in Chongming Island, we wish to concentrate on five. First, as we have already noted above, there is a need to recognize state authoritarianism (Xie, 2015), which shapes the development process, 
opportunities for participation and dominant interpretations of nature. The state is also riven by tensions as it acts as both developer and protector of the environment, and these tensions play out in spatially complex patterns, suggesting the need for detailed local analysis. Second, as a consequence of state authoritarianism, voices of dissent may be more covert, what have been termed 'persistent persuaders' (Lang and Xu 2013) and will certainly be subtle. We have therefore listened carefully to what is said to us and also to what is not said. This point is developed further in our methodology below. Third, there is a narrative that rural villagers are backward and unwilling to manage land in an environmentally sensitive manner, which helps provide a rationale for state activity (Yeh, 2015: 624). As we shall see, on Chongming Island there are competing knowledge claims between local know-how and external professional expertise. Fourth, recognition needs to be given to the ways in which the environment is constructed, reconstructed and deconstructed (Leff, 2015). Both EM and Chinese policy has a narrower view of the environment than that to be found in political ecology. A more anthropocentric perspective matters greatly in how win-win outcomes can be created. Meanwhile, residents on Chongming tend to have a more intuitive and eco-centric perspective on the environment which rejects or at least does not connect with an anthropocentric rationality. This allows us to begin to explore the potential for local forms of resistance in society-environment relations, though recognizing that opportunities are curbed by state authoritarianism. Fifth, the Island is also a rural space, the traditional heart of political ecology (Leff, 2015), but it is also part of the much larger urban-industrial complex of Shanghai that drives processes of scaling (Barca and Bridge, 2015). In a state-driven economy that seeks to control planning and development, scale becomes both a contextual and an explanatory factor in our account of ecological relations on Chongming. For example, Chongming can be portrayed as an eco-Island, almost detached from Shanghai, a place that is to be a model of sustainable work and living. Chongming can also be described as the green lungs of Shanghai, in which case it becomes possible to justify further urban land intensification because a high-quality green space is being preserved within the city boundary. Both of these constructions of Chongming have implications for the citizens of the Island and whether or not spaces within a city can be socially, environmentally and economically equitable.

Therefore, political ecology, within this research, both serves as a productive and persuasive theoretical framework that gives emphasis to socio-environmental changes and effects, that is inclusive of stakeholders, and has a normative component to helps our assessment of current Chinese eco-development practices.

\section{Case selection and methodology}

In this research, we ground our analysis via a case study of Chongming Eco-Island in China. This is for three major reasons. First, Chongming has from the outset been the central locus of Chinese eco-development practice and thus has witnessed and embodied the features and evolution of Chinese state sustainability innovations and ideals. Chongming typifies state-led planning ecoinitiatives. In 1996, Chongming County was selected as one of the pilots for constructing the National Ecological Demonstration Zone, and successfully attained the award in 2002 (MEP, 2002). In 2005, the Dongtan Eco-city project, which is located at the east end of Chongming, was launched with a claim to be the world's first purpose-built eco-city (Arup, 2008, Head and 
Lawrence, 2008). It represents China's first attempt at building a sustainable urban model from scratch (Pow and Neo, 2013). Although this renowned project has been indefinitely suspended since 2008 due to a complicated set of reasons (cf. Chang and Sheppard, 2013, Cheng and Hu, 2009), its planning and development ideas and methodology have, in some respects, influenced the wider plan of Chongming Eco-Island project, and further inspired subsequent eco-initiatives in China (such as the flagship Sino-Singapore Tianjin Eco-city) (Chang and Sheppard, 2013, Pow and Neo, 2013). One year after the publication of the Dongtan eco-city project, the Shanghai Municipal Government and Chongming County government issued the "General Plan for Chongming Three Islands" (hereafter referred to as "General Plan"), announcing the decision to develop Chongming Island and two small surrounding islands (Changxing and Hengsha) into "ecoislands" (Shanghai Municipal Government. 2006) ${ }^{2}$. Since then, Chongming has undergone more than a decade's construction, and now there is an ambition to build a world-class eco-island (Shanghai Municipal Government, 2016b). Therefore, understanding Chongming Eco-Island, to some extent, contributes to the achievement of a deep insight into urban sustainable/ecological practices in China. A second reason for the case study selection is that whilst the majority of ecodevelopment practices are conceived of or delivered primarily in terms of technological innovations, Chongming Eco-Island have been recognized as prioritizing a more integrated sustainability vision and planning approach (Joss et al., 2011). It is anticipated by UNEP that Chongming can serve as a model of China's eco-progression, and an example of developing an ecological economy for less developed regions of the world (UNEP, 2014: 96). With such a positive reputation among Chinese eco-developments, Chongming thus serves as an ideal case for our critical examination of current Chinese eco-developments. Third, the existing complex social structure, the abundant ecological resources, and the rich historic and cultural contents of Chongming endow it with both political and ecological value. Whilst a significant number of ecocities are being built in the tabula rasa way locating on brownfield sites and largely constructed from scratch (Joss et al., 2011), Chongming Eco-Island is planned and constructed on high quality rural land with diverse landscapes ranging from wetlands, crop fields, and forest, and is home to nearly 700,000 people who have nurtured a rich culture.

To critically examine the development of Chongming Eco-Island from a political ecology perspective, the empirical sections of this paper are built upon data collected through archival research, interviews with a multiplicity of stakeholders, and on-site observation. We brought in to the study a host of actors and stakeholders, including governmental officials, planners, academic researchers, farmers, indigenous residents, and tourists, to explore their knowledge, perceptions, and evaluations of the Eco-Island development. From November 2016 to September 2018, we have conducted in total nine fieldwork visits to Chongming with an average duration of 6 days. To understand the practices and to evaluate the effects of Chongming Eco-Island development, data is organized around the three major dimensions of sustainability, namely environment, economy and society. In our archival research, we conducted analysis of governmental policies and plans to understand how local states (i.e. Shanghai Municipal

\footnotetext{
${ }^{2}$ Changxing Island and Hengsha Island, which were originally under the administration of Baoshan District of Shanghai, have been transferred to the jurisdiction of Chongming County in 2005 (State Council, 2005). This paper focuses on Chongming Island but will touch on the other two islands when involving policies and plans that apply to all three islands.
} 
Government and Chongming County/District Government) interpret the notion of ecodevelopment, how they depict their vision of Chongming Eco-Island, and what methods and actions are implemented to achieve such a vision. To evaluate the performance of these practices, we then draw on a wider variety of documents including reports from both governmental and non-governmental organizations, press coverage, and academic publications; and quantitative evidence from Chongming Statistics Bureau and Shanghai Municipal Government to describe the socio-economic and environmental changes.

Through the archival research and personal networks, we identified key informants in local planning and research institutes as well as in academia for interview. Interviews took place on Chongming Island as well as in the city of Shanghai. In total, we have conducted in-depth interviews with six planning professionals, six academic experts, three local cadres and two representatives from local enterprises on Chongming, who are closely involved in or have conducted research work on the Eco-Island project. Through the interviews, we were able to trace the development of Chongming in terms of its governance and policy delivery, as well as to understand the views of planners and researchers on the Eco-Island construction. Moreover, 28 semi-structured interviews have been conducted with local residents, indigenous farmers, and tourists. In undertaking the interviews and identifying interviewees we were sensitive to our understanding of the authoritarian state (see above). We carefully listened to the voices of those who spoke to us to detect nuances in meaning. We also actively sought out those who are not typically heard (such as farmers, older people and women). The levels of trust that we were able to develop in the community culminated in informal focus group meetings with villagers from Hongqiao Village. The first of these on $31^{\text {st }}$ March 2018, lasted for three hours. The meeting was attended by three male and one female elderly (above 60 years old) villager. They shared their memories of the Island's past, their childhood and youth experiences, and their life changes and their attitudes towards the eco-developments on the Island since the 2000s. Following this, another two informal focus group meetings were carried out on September 12, 2018. The first was with three male and two female elderly villagers and the second with four male and three female elderly villagers. These focus groups had three objectives: 1) provide a voice for grassroots' accounts of policy and planning implementation and their consequences; 2) address how local stakeholders perceive ecology, environmental protection and improvement, socio-economic progress, and the notion of an eco-island; and 3) understand and further evaluate the on-theground construction in detail to better understand how that in turn may reconfigure notions of a local environment. Thus, this paper draws heavily on the interview data, triangulated with archival research, focus groups and on-site observation. As this study presents both official narratives and implementation practices, and voices from policy/planning-makers and grassroots actors, it shows a) the contradictions and conflicts in the Chongming Eco-Island development, and b) how the state utilizes the planning process, especially key documents, to promote its EM perspective on eco-development. These issues are discussed further below.

\section{Case Study: Political Ecology of the development of Chongming Eco-Island}

The empirical materials are organized to draw out the key environmental, economic and social issues shaping the development of Chongming Island. Within these themes particular attention 
is paid to dominant accounts that draw upon an EM perspective to understand developments, and an emergent counter narrative that is more sympathetic to Political Ecology. The counter narrative brings together people, place and the environment and shows how place matters to people, how people's experiences of their environment on a day-to-day basis shape how they perceive resource and environmental changes, and that by adopting a political ecology approach we can give a voice to those who are marginalized in policy-making processes. We argue that whilst local communities and some key actors are becoming increasingly aware of the tensions in seeking to promote eco-development on Chongming Island, influences from EM type thinking are likely to remain highly significant in official policy narratives.

An analysis of the Chongming Eco-Island project cannot sidestep its precursor - Dongtan eco-city. Empirical research digging into the genesis and development of Dongtan eco-city has unveiled its commitment to a weak form of sustainability, which aims to integrate economy with ecology (but lacks a similar analysis of social development). More bluntly, it sought to capitalize on the natural resources of Chongming for sustainable economic development (Chang and Sheppard, 2013, Sze, 2015). Adopting a principle of EM that assumes an eco-city can be built through "technological fix" methods, the plan of Dongtan project featured novel environmental technologies and green industries. Although not many of the facilities outlined in the plan have materialized at Dongtan (Den Hartog et al, 2018), the Dongtan wetland park and a wind farm that consists of 13 wind turbines are evidence of this ambitious plan. Whilst the Dongtan eco-city project has stalled since 2008, its planning idea(I)s and methods have been extended to the broader plan of Chongming Eco-Island (Chang and Sheppard, 2013). The first master plan for building Chongming Eco-Island - the "General Plan" issued in 2006 - lays a cornerstone for the ecological development on the Island. The "General Plan" has largely adopted the proposal from the Shanghai Urban Planning and Design Institute (SUPDI), which highlighted three key principles, namely: 1) adhering to an EM pathway to leapfrog traditional industrial urbanization; 2) conserving natural ecological spaces and securing land capacity for future international projects; and 3) adhering to the "three concentration" principle (i.e. concentrating land operations, industrial development, and farmers' residences) to effectively solve the "Three Agricultural Problems" (problems of rural areas, rural population and agricultural industry) (SUPDI, 2005, pp.5-6). It is important to note, that rural areas and their communities are being framed as a problem to be solved by urban professionals promoting an EM agenda. The value of local people and their environmental knowledge was marginalized. As we shall see below, this has made the approach to building an eco-island more problematic as local people have sought to rescale expertise and decision making to the Island so that their concerns could be more fully recognized. However, the authoritarian and hierarchical nature of the state and the operation of local planning processes have largely inhibited these efforts but have been unable to halt the development of a counter narrative.

\section{1 “Plus Eco" - Environmental Assessment}

In this section, we outline how a key government strategy - "Plus Eco", which refers to environmental construction to further enhance existing ecological base on the Island - drew upon EM thinking in its conceptualization of the environment. We then analyze how a more ecologically informed counter narrative came into play. 


\section{Ecological Modernization and eco-development}

Natural capital is typically identified as the only resource enabling development of Chongming Island (Chang and Sheppard, 2013), and there is little doubt of its value in the planning of the Eco-Island. However, questions arise: what aspects of the environment are cherished and by whom? What measures were taken to protect or improve them? Who decides what is of environmental value? Proposed strategies in the government plans and policies are, not unexpectedly, all-embracing, covering a wide variety of aspects of the environment such as water, vegetation, soil, atmosphere, acoustic environment and other ecological elements. We start off by looking at the stipulated key performance indicators (KPIs) of the Eco-Island (Table 1) (Shanghai Municipal Government, 2016). Since the indicator system provides quantitative measurement for the success or otherwise of the implementation of Eco-Island construction, these indicators matter to government and developers. For example, for the former the indicators serve as a key evaluation criterion for local cadres' performance, while for the latter they set boundaries to development and thus illustrate where environmental and economic issues interact. Also problematic is that the indicators tell us little about their means of delivery but these may also be unsympathetic to local practices (as illustrated by the example of river canalization below). As it is shown in Table 1, targets are divided into two types: anticipated and obligatory. As the latter can be understood as being accorded "veto power" status, meaning that, whether or not these targets are achieved would directly affect the promotion of the responsible cadres to upper-level positions, it can be seen that the performance of environmental improvement on Chongming Island mainly depends on increasing natural resources (including forest and wetland), and improving environmental quality. These measures are incorporated into the "Plus Eco" strategy of Chongming Eco-Island development (Shanghai Municipal Government, 2018). Whilst these measures are laudable and clearly demonstrate the efforts that are being made to improve the environment and quality of life of Chongming's inhabitants, they represent a top-down and techno-scientific approach and calculative governmental logic to environmental management (Ma et al, 2017; Pow, 2018). These are the measures favored by Municipal Government planners and allied professions (e.g. engineers, landscape architects) and are sympathetic to national policy goals, such as Ecological Citizenship. In turn, these measures will be delivered by professionals (e.g. river engineers) working to external quality criteria. So, neither the measures nor their means of delivery may meet with local people's aspirations.

Table 1. Key indicators of Chongming Eco-Island development

\begin{tabular}{|l|l|l|l|l|}
\hline No. & Indicators & Attribute & 2015 & 2020 \\
\hline 1 & Forest coverage rate (\%) & Obligatory & 22.53 & 30 \\
\hline 2 & Natural wetland retention rate (\%) & Obligatory & 38.07 & 43 \\
\hline 3 & $\begin{array}{l}\text { Number of waterbird species accounting for } \\
\text { more than 1\% of the global population }\end{array}$ & Anticipated & 7 & 10 \\
\hline 4 & $\begin{array}{l}\text { Surface water environmental functional area } \\
\text { compliance rate (\%) }\end{array}$ & Obligatory & 78 & Approximately 95 \\
\hline 5 & Urban sewage treatment rate (\%) & Obligatory & 85 & 95 \\
\hline 6 & Rural sewage treatment rate (\%) & Anticipated & 76 & 100 \\
\hline 7 & Recycling rate of domestic waste resources (\%) & Anticipated & 28.8 & 80 \\
\hline
\end{tabular}




\begin{tabular}{|l|l|l|l|l|}
\hline 8 & $\begin{array}{l}\text { The rate of good ambient air quality (AQI } \\
\text { measurement) (\%) }\end{array}$ & Obligatory & 74.8 & 78 \\
\hline 9 & Resident population (Ten thousand) & Obligatory & 69.6 & Approximately 70 \\
\hline 10 & Construction land $\left(\mathrm{km}^{2}\right)$ & Obligatory & 262 & $\begin{array}{l}265 \text { (3 } \mathrm{km}^{2} \text { less } \\
\text { than the original } \\
\text { planned } \\
\text { construction } \\
\text { land) }\end{array}$ \\
\hline 11 & $\begin{array}{l}\text { The average growth rate of energy consumption } \\
(\%)\end{array}$ & Obligatory & $/$ & No more than 2 \\
\hline 12 & $\begin{array}{l}\text { Reduction rate of energy consumption per unit } \\
\text { of GDP (\%) }\end{array}$ & Obligatory & $/$ & 17 \\
\hline 13 & Renewable energy installed capacity (10MW) & Anticipated & 29 & 50 \\
\hline 14 & Gigabit network coverage rate (\%) & Anticipated & $/$ & 100 \\
\hline 15 & The proportion of green transportation (\%) & Anticipated & 76 & More than 80 \\
\hline 16 & Green food certification rate (\%) & Anticipated & 27.5 & 90 \\
\hline 17 & Per capita income for rural residents (\%) & Anticipated & $/$ & $\begin{array}{l}\text { More than } \\
\text { doubled than } \\
2010\end{array}$ \\
\hline
\end{tabular}

Source: Shanghai Municipal Government, 2016

The indicators in Table 1 provide a valuable insight into the technocratic criteria that present how spatial planners and engineers 'imagine' the rural environment of Chongming Island. The indicators are an important instrument to help to shape the environmental backdrop against which local, oppositional voices seek to be heard. The indicators are largely a mixture of resource management to enhance the rurality of the Island (e.g. through tree planting); and infrastructure provision (such as sewage treatment) to modernize it. Perhaps surprisingly for a flagship ecodevelopment, Indicator No 8 on air quality is set at 78\% by 2020, below the national target (AQI should reach $80 \%$ by 2020 ), as stated in the "Three-Year Action Plan for Winning the Blue-Sky Defense War" (State Council, 2018). An important clue as to why the AQI target for Chongming Island is lower than expected is because Shanghai, to which it is in close proximity, is also falling below the target and performing more poorly than many other urban areas (China Daily, 2018; Shanghai Municipal Government, 2016 \& 2018).

Although the AQI Indicator might suggest that targets are set that can be met, Chongming County/District Government does take them seriously and has enforced a series of measures over the years to ensure their attainment. For instance, factories on the island that have an unsatisfactory record of environmental protection were ordered to improve or face closure. In total, more than 1,000 factories have been shut down over 15 years (the total number of factories of Chongming County has declined from 1531 in 1990 to 529 in 2004) (Chongming Statistics Bureau, 2017). Meanwhile, massive tree planting and infrastructure construction have been carried out on the Island: from 2000 to 2015, the forest coverage rate on the Island has risen from $10 \%$ to $22.53 \%$; and the urban and town sewage treatment rate has increased from $10 \%$ to 85\% (Shanghai Municipal Government, 2016b). In addition, currently, Chongming's water quality ranks as the highest in the city. The environmental measures adopted in the Eco-Island 
construction are widely praised among both planners and academic researchers. The following comments are typical:

Positive environmental outcomes have been achieved during the development of the Eco-Island: there no longer exists polluting industries; green land has expanded; and the number of migrant birds remains stable. Above all, the power of the capital is so fierce that it can bring dramatic change to the Island in the blink of an eye. Shanghai and local government have tried their best to avoid this.'

Without the Eco-Island policy and plan, Chongming would be surely encroached by the fierce urbanization movement from both Shanghai and Jiangsu province. The EcoIsland plan has protected Chongming's natural environment and has provided Shanghai residents with a "backyard garden" for leisure and entertainment."

Indeed, compared with the rapid advancement of urbanization in other districts in Shanghai, Chongming has largely managed to maintain its rural and pastoral scenery. Its relatively clean and high-quality environment has attracted both tourists who are seeking a getaway from the boisterous and busy city life, and organic farmers who are devoted to promoting healthy food.iii

\section{A Counter Narrative: The Emergence of Ecological Concerns}

However, different voices were raised contesting the ecological measures enforced on the Island. A local resident in Hongqiao Village in Chongming, who is also an environmental activist that constantly petitions the government about environmental measures, expressed her observations and criticisms:

From what I observed and experienced, Chongming suffered the worst ecological transformation in the past ten years. Those ecological projects enforced by the government are actually destroying our ecological nature day by day. The most severe problem is the river regulation. Projects enforced to harness rivers and riverbanks adopted traditional hardening techniques, cementing the original natural riverbank with an impermeable concrete retaining wall, which cut off the exchange of material, energy and information between rivers and the banks, and thus disabled the rivers' self-purification abilities. Meanwhile, as the village sewage treatment has not been improvediv, the quality of processed wastewater that directly emitted into rivers is very low, which profoundly threatens the river water environment. Consequently, rivers on the Island were persistently polluted, which gravely harms the aquatic organisms and further induces biodiversity loss."

The resident's narratives disclose the engineering measures employed in constructing the environment on Chongming Island, which is in line with the guiding EM principles adopted in the Eco-Island plans. These EM principles included emphasizing scientific and technical perspectives, especially of engineers and landscape designers (with a consequent marginalization of local knowledge and expertise); an emphasis on resource efficiency (e.g. in land use, water flow), and urban aesthetics (e.g. in landscape design) (Pow, 2018); and the use of technology and techniques 
to manage the environment (e.g. straightening rivers). On-site surveys enabled the authors to empathize with the resident's concerns, as we observed the majority of the numerous rivers on Chongming had been cemented and elaborately-trimmed (Figure 1). During the longitudinal study, the authors also documented the transformation of a river alongside the Xinjiang Road before and after the riverbank construction (Figure 2). On November 14, 2017, as we came across this river that still maintains its natural state with wild plants by its banks, we found a truck laying down concrete columns by the road preparing for the river regulation project. Four months later, we revisited the river and found that the implementation of the project has totally transformed the landscape of the river. Concrete columns have been installed and typical riverside vegetation has been eradicated to be replaced by a managed, neat and manicured green. Alongside these visual changes will be the disappearance of the river's original and natural ecology.

Figure 1. Riverbanks have been transformed during the river management on Chongming
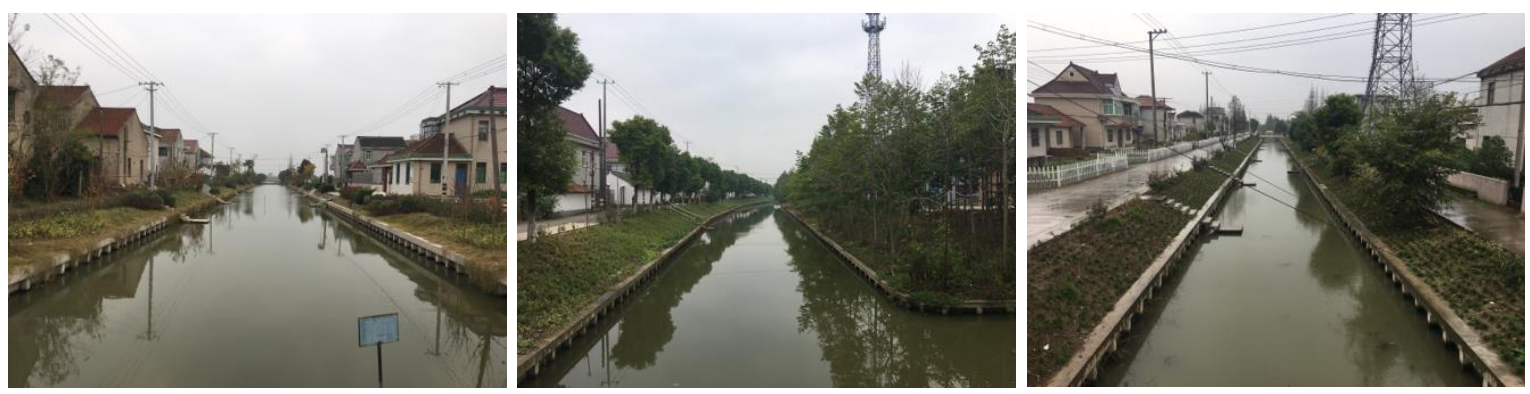

Source: Authors.

Figure 2. The transformation of Xinjiang Road River under the river project from 14-11-2017 to 29-03-2018.
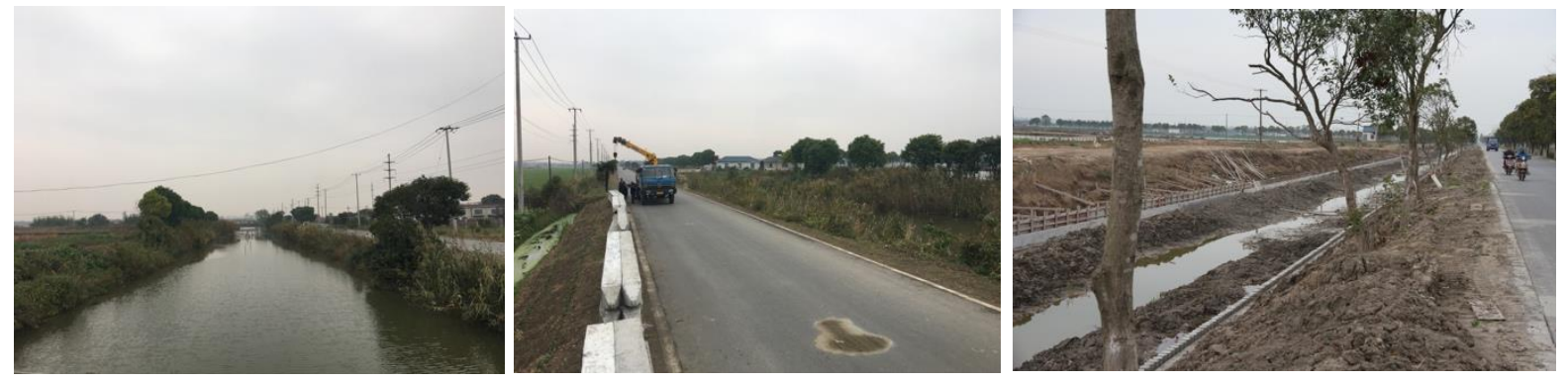

Source: Authors.

In fact, river regulation has been performed on Chongming Island since 2006. At this time, along with the release of the "General Plan" of building an eco-island, Chongming began to implement the "Ten-Thousands Rivers Regulation Operation" (Wan He Zheng Zhi Xing Dong) and completed the transformation of nearly 5,000 rivers. In 2009, as a continuation of the "Operation", Chongming further implemented the "Village and House River Regulation" (Cun Gou Zhai He) and completed the modification of more than 4,000 village- and house- level rivers. Since 2011, another series of projects, including "Ecological River Regulation" (Sheng Tai He Dao Zheng Zhi), 
"Medium and Small Rivers Maintenance" (Zhong Xiao He Dao Yang Hu), and "Village-level Rivers Dredging" (Zhen Cun Ji He Dao Lun Shu), have been launched and performed on the Island. Yet, it is perplexing why these operations with an intention to treat water pollution and to improve water quality materialized on the ground as an engineering method that undermines the river ecology.

As we probe into the motivations behind the river regulation practices on Chongming Island, the orange billboard which can be found on every river on the Island sheds some light. The billboard is put up by the Chongming River Chief System Office to indicate the first-level and second-level river chiefs (normally held by a town cadre and the village head), who are responsible for the management of the river environment, and their working objectives. It is clearly stated on the billboard that the detailed management of the river environment involves "no crops in the streambank and river platform, no illegal constructions, no piles, no garbage, no fallen trees, no floaters in the river surface, no obstructions in the river channel, no illegal emissions, no withered plants in and by the river" (Figure 3). Considering the common quick responses of local officials to the superior governments' instructions, local cadres (river chiefs) on Chongming would seek for the most efficient solutions that can generate rapid and visible effects. This is supported by our interview with a former "river cleaner" hired by the Chongming Water Authority in 2007, who said that in order to pass the monthly inspection by the government (failure to deliver the tasks will lead to salary deduction), river cleaners resorted to the usage of herbicides to clean the riverbanks. ${ }^{\text {vi }}$ Therefore, apparently, cementing the river bank is a quick solution to address all of the requirements stated on the billboard. Biodiversity and natural wildness are outside of the scope of performance assessment and thus out of local government officials' consideration during the development process.

Figure 3. Billboards put up on the riverbank by the River Chief System Office of Chongming.

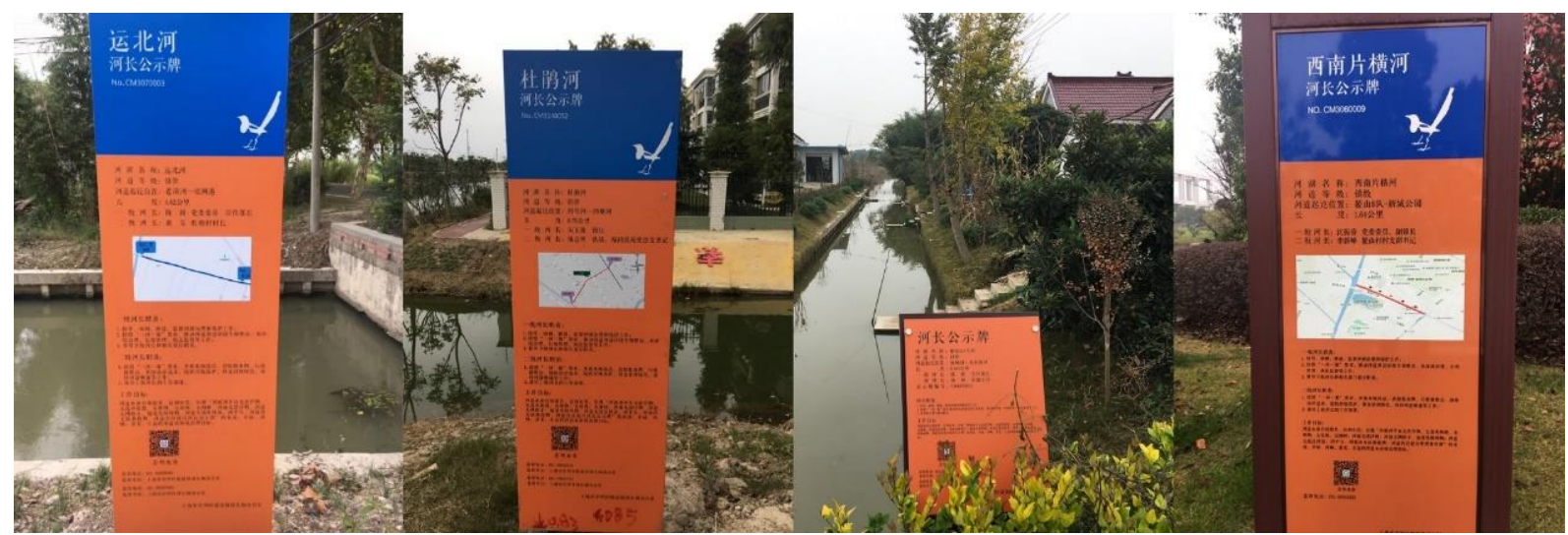

Source: Authors.

Similar logic and practices have been shown in the massive afforestation on Chongming Island. To expeditiously increase the forest coverage and greenery rate outlined in the Eco-Island Plan, local cadres on Chongming employ unitary tree planting without much concern about nature and ecology. As a local resident describes the situation: 
Another unsettling action taken by the government is the extensive afforestation on the Island. In recent years, much of the farmers' land has been expropriated or transferred by local government to construct the so-called "non-commercial forests" (gong yi lin). In a pursuit of efficiency and profit, most of the trees planted are largely composed of fast-growing and unitary species. vii Since then, wild animals are gradually disappearing and even birds are leaving. What has been built here is an urban eco-island, not a rural eco-island. viii

Acres of newly-planted, neatly spaced trees are spread across Chongming, while the local ecological environment and biodiversity have been severely damaged, causing irreversible changes. Two indigenous elderly farmers reflected on the situation:

Before the Eco-Island construction, the Island was scattered with patches of bamboo forests and mulberry trees. You can hear the cries of birds and the hum of insects everywhere. There were reeds by the rivers. The water was very clean, and had a variety of creatures such as fish, shrimp, crabs and eels. That was the natural beauty of our home, but unfortunately it does not exist anymore. ${ }^{\text {ix }}$

Neat, it is very neat everywhere - this is the main feature of Chongming now. Even the flowers and trees by the river and the road are neatly organized. But does neat means beautiful or ecological? Not necessarily... As in the past when every household manages their section of the river and the road, growing different flowers, vegetables and trees, it was very beautiful and ecological to me, and you could collect fruits and vegetables from them. Children loved to play in the river, but now it is no longer possible to do so. ${ }^{x}$

Whilst the local people mourn and condemn the ecological constructions that have taken place on the Eco-Island, planners and governmental officials are gratified by the achievements demonstrated by the statistics on the renovated and managed beauty. A more chaotic and untidy traditional nature to be found on the Island and which is so valued by local people, gives way to one that is state approved and can be measured. This radical divergence of attitudes results in serious disputes over what is a "good" environment. From a political ecology perspective, these disagreements stem from different groups' different knowledge and diverse interests in "place" and "resources" (Bryant and Bailey, 1997, Neumann, 2005, Peet et al., 2011, Robbins, 2012). There is, moreover, a key role for the state in directing environmental change: local cadres whose primary motive is to meet their political targets tend to be sympathetic to engineering and modernizing environmental measures. Meanwhile, local people who have a strong emotional attachment to their land and the natural environment strongly oppose such actions. However, due to the overwhelming power possessed by the government, grassroots' voices are largely ignored and they exert negligible, if any, influence on the Eco-Island development. 


\section{2 "Eco Plus" - Economic Assessment}

A key feature of EM is its claim to marry together economic and environmental imperatives for mutual benefit. The "Eco Plus" strategy, as proposed in the Chongming Eco-Island plan, is to build up ecological services of the Island, such as tourism and clean production industries. In this section, we examine the nature and extent of economic benefits arising from the efforts of Shanghai Municipal Government and Chongming County Government to create an eco-island.

\section{Ecological Modernization and a Green Economic Boost}

Inheriting Dongtan's approach, the advocates of eco-island construction were keen to support the development of green industries. In the "General Plan", land on all three islands was carved up and zoned into several functional regions, including ecological system demonstration areas, leisure and tourism, sport and vacation, education and innovation, theme park, and conference center and offices (Shanghai Municipal Government, 2006). The subsequent "Chongming EcoIslands Development Outline (2010-2020)" issued by the Shanghai Municipal Development and Reform Commission (SMDRC) (2010) further highlights three main industries, namely ecological agriculture, clean and high-tech ecological industry, and modern service industry. In 2016, the "Eco Plus" development strategy was officially written into the "Thirteenth Five-Year Plan for the Economic and Social Development of Chongming (2016-2020)", aiming to "increase ecological assets, to reduce ecological liabilities, and to develop an ecological economy" (Shanghai Municipal Government, 2016). The strategy was interpreted as to "promote the integration of ecology and industry, science and technology, and social wellbeing, so as to enrich the connotation of ecological progression and transform the ecological advantages into development advantages" (Chongming County Government, 2016). In short, the "Eco Plus" strategy further reinforces the commitment to drawing economic benefit from environmental resources, echoing EM's growth-driven underpinnings.

As the EM ideas and the Eco-Island plan gradually materialized, the physical fabric of the Island has been substantially changed. In Chenjia Town - one of two key development areas on Chongming Island (the other is the old town of Chongming - Chengqiao Town), ten functional zones were initially deployed, covering the original base of the Dongtan eco-city (Figure 4). This has catalyzed the completion of several "ecological villages" that aim for eco-tourism, organic farms, modern residences, villas, two golf courses with upmarket hotels, and a few office buildings. Benefiting from the upgrading of tourist service facilities and the environment, the tourism industry on the Island has witnessed considerable growth. Along with the opening of the Shanghai Yangtze River Tunnel-Bridge in 2009, which directly connects the east of Chongming Island and central Shanghai, tourism revenue nearly quadrupled from 2008 to 2016, rising from 272.53 million to 1090 million RMB (Chongming Statistics Bureau, 2017). However, tourism in Chongming remains largely limited to the weekend and holiday season and has not yet evolved into a strong economic sector; tourism only contributes a small amount of the Island's revenue (approximately 3.5\% in 2016) (Chongming Statistics Bureau, 2017). 
Figure 4. The General Plan of Chenjia Town (2009 - 2020) and its regional spatial layout.

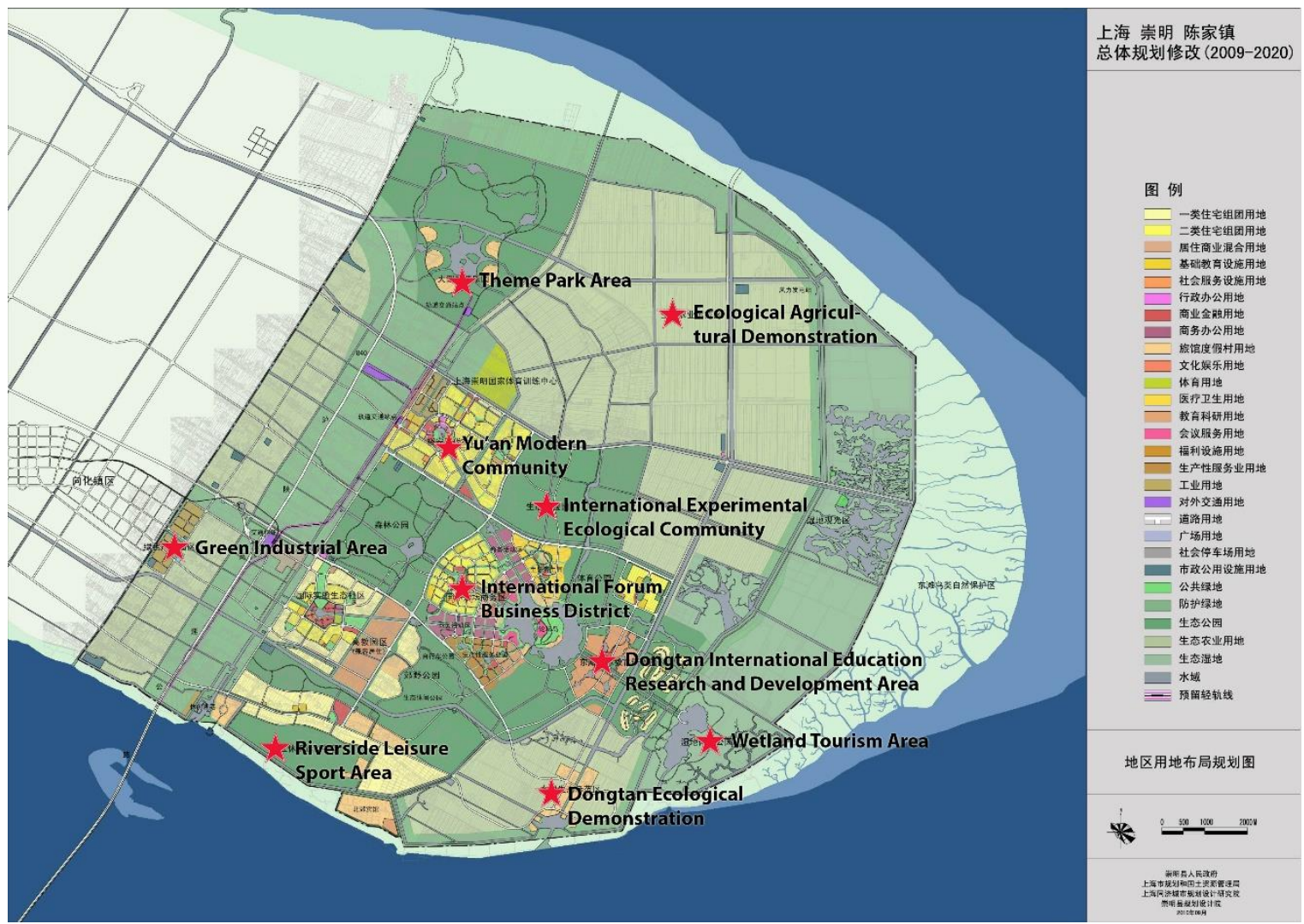

Source: adapted from Shanghai Municipal Government (2010).

\section{Implementation reality: Stagnant Economic Development}

Despite development of the tourism industry, the economic outcomes seem to be a far cry from the expectation as little progress has been shown in other proposed industries on the Island. Apart from the quickly-built real-estate projects and big blocks of residences to accommodate the relocated farmers whose homes were demolished to create space for the planned industries, the site proposed for the construction of the International Forum Business District remains largely as flat fields of vegetables and brownfields surrounded by newly-built modern residences (Figure 5). Moreover, as of mid-2018 only the first phase of the Sport Training Base and the office buildings of the Shanghai Wisdom Island Data Industrial Park are under construction but building is taking place at a very slow pace. 
Figure 5. Wide open field at the site planned for International Forum Business District of Chenjia eco-town

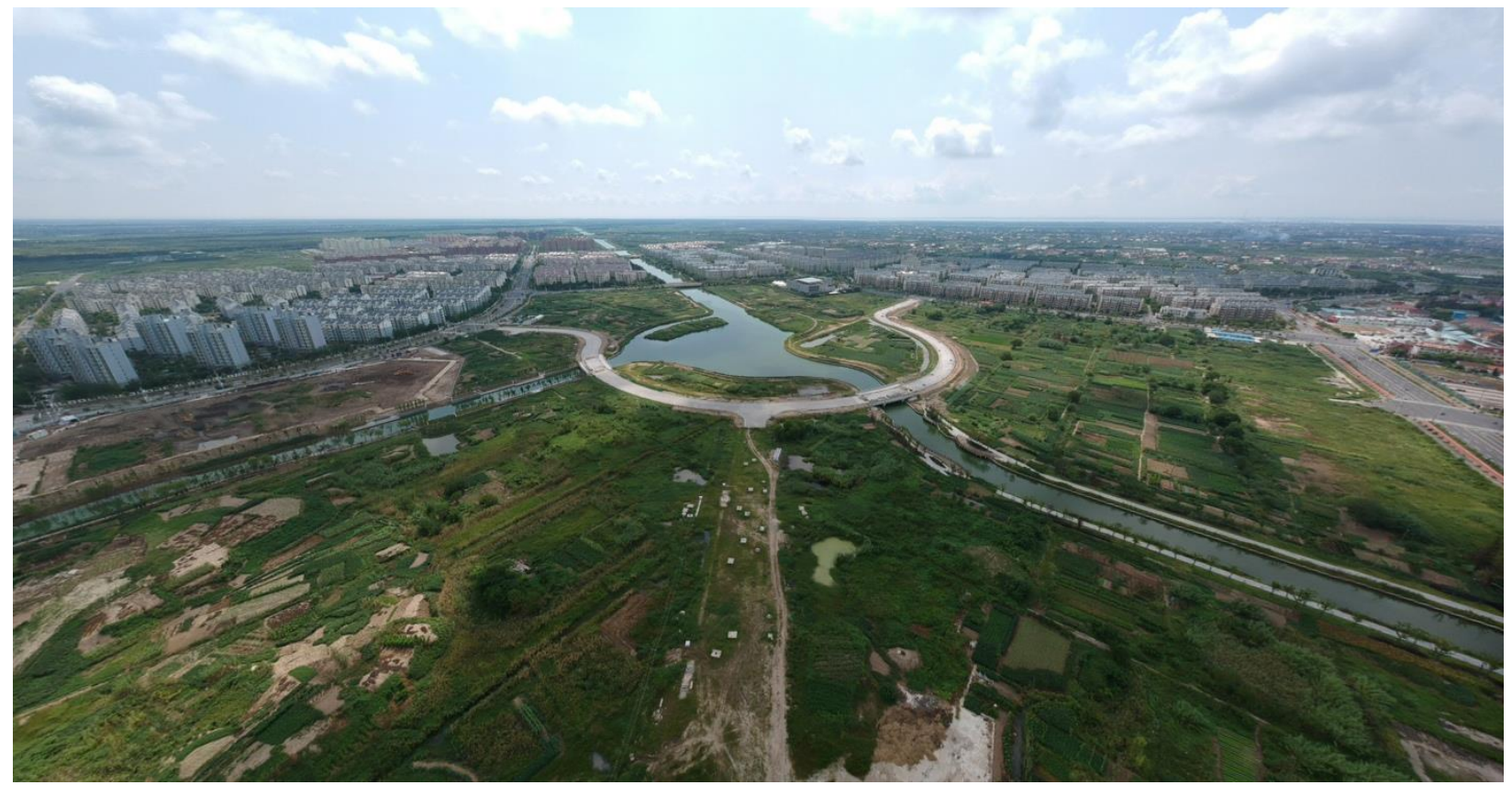

Source: Authors.

Meanwhile, as shown from the research conducted by planners from the China Academy of Urban Planning and Design Shanghai Branch (CAUPD-SB), Chongming has been suffering from a severe hollowing out of industry after the large-scale removal of the backward and polluting industries in the late 1990s. An analysis of Chongming County's revenue composition in 2014 reveals that $85 \%$ of the County government's enterprise revenue comes from "registered enterprises" (enterprises who are registered in and paid taxes to Chongming, but are located outside of Chongming), with merely $15 \%$ of revenue from enterprises on the island (Ge \& Zhang, 2016). In the meantime, Chongming has been relying heavily on transfer payments from Shanghai municipal government to maintain its fiscal balance and governmental operation, as the transfer payment income accounts for 60\% of its governmental income in 2014 (Chongming Finance, 2015). Clearly the economy on the Island remains stagnant.

One might argue that a sluggish local economy could arise because of the long distance from Chongming to central Shanghai which discourages investors (Chang and Sheppard, 2013). However, our interviews with local bureaucrats and planners provide further insights. For example, a local government official argued that:

The reasons for the slow development are really complex. What was planned in the first place might be proved to be inappropriate for the Eco-Island. For example, the theme park area in Chenjia Town, which was proposed and reserved for Disneyland, was criticized for its adverse impacts on migratory birds and for its connected effects that could jeopardize the fragile environment on the Island. Meanwhile, the policy 
volatility of Chongming also discourages potential investors. The Dongtan project led by the Shanghai Industrial Investment Company (SIIC) is a vivid example as its construction land has been again and again cut short by the government. ${ }^{\mathrm{xi}}$

Meanwhile, according to a local planner:

Before the opening of the Tunnel-Bridge, the inaccessibility of Chongming was obviously the major constraint for local development. However, the opening of the Tunnel-Bridge did not change the situation as it charges 50 RMB toll per trip. In my own opinion, it shows that the Shanghai government is still reluctant in developing Chongming. So, on the one hand, it did not vigorously promote industrial development; on the other hand, it provides substantial financial support for Chongming County to support the local development needs. ${ }^{\text {ii }}$

It is evident that the original plans were poorly conceived with insufficient consideration of the local environmental context and so were always likely to fail in their implementation. Meanwhile, as the (Municipal) Government plays a decisive role in Eco-Island development, its policy swings have a significant impact on promoting or curbing Eco-Island development. Chongming remains the least developed area of Shanghai (UNEP, 2014).

Since the autumn of 2016 another significant transformation of policy and planning has been taking place on Chongming. Interviews with local developers, bureaucrats, planners and academic researchers all agreed on the nature of an ongoing reform on the Island in which nearly all developments and construction on the Island was stopped by the Shanghai Municipal Government. Since late 2016 no new development permits can be issued. The halt in development followed a visit to the Island by a senior political leader of Shanghai in September 2016. He heavily criticized the nature of development on Chongming and pointed out that as an eco-island, its key development areas showed no difference from other urbanized districts of Shanghai, and thus called for (i.e. required) immediate change and reform to the pattern of development. As the political leader orders a reconsideration of the previous plans and actions and a search for new visions and plans begins, so the EM-guided practices are under challenge. Nevertheless, EM remains the most important framework that will be utilized by consultants and officials in producing future plans. Once again, it is the state shaping development on the Island and marginalizing alternative eco-development perspectives.

\subsection{The Underemphasized Pillar - Social Assessment}

Ecological modernization is at its weakest in addressing social issues (Gouldson and Murphy, 1996, Pepper, 1998). It is not surprising, therefore, to find that social issues and how they interact with the economy and environment have been amongst the most neglected in debates on the development of Chongming Island. Here, there has not been a counter narrative developed to challenge official perspectives as the official view has been so weakly formulated. Whilst at an abstract level the eco-island plan purports to achieve a "beautiful environment, intensive usage of resource, and coordinated development of the economy and society" (Shanghai Municipal Government, 2006), in practice there is a mismatch. Among the 22 key indicators raised in the 
Chongming Eco-Islands Construction Outline (2010-2020), only two indicators are linked to a social dimension, namely "public satisfaction rate with the environment" and "per capita fiscal expenditure of social undertaking development" (SMDRC, 2010). These two are not even directly linked to "social well-being" nor "social justice", which are the two key themes concerning social sustainability (Liu et al., 2017). Rather like environmental investment, social investment has been a top-down agenda item with few measures taken to address local people's needs and issues. Consequently, Chongming is beset by numerous social problems, including outmigration and an ageing population, and the decline of people's living standards.

Chongming is continuously suffering from labor outmigration. Due to the mass closure of industrial enterprises and the absence of alternative industries, employment is reducing significantly on Chongming; the number of industrial workers decreased from 161,547 in 1990 to 58,066 in 2004 (Chongming Statistics Bureau, 2017). As more and more of the working-age population leave the Island to seek work in central Shanghai or other cities, the number of "Elders Living Alone" is growing (Chongming County Government, 2017). The ageing problem is becoming more severe as the population above 60 years old on Chongming has surpassed 0.21 million, taking up 32.6\% population of the registered population in 2015; and it is expected to exceed 0.25 million in 2020, occupying $38 \%$ of the total population (Chongming County Government, 2017). Outmigration and the ageing population not only pose a series of social problems and challenges, but also effect prospects for future economic development and people's well-being.

Due to the shortage of alternative employment, most of the remaining residents are still engaged in farming. Their household income and living standards remain relatively low. This is even more prominent for those households whose land has been transferred to construction or forest land. As guided by the "Three Concentration" principle, the Eco-Island development plans to centralize rural residences and to increase the urbanization rate from 41.7\% in 2016 (Chongming Statistical Society, 2017) to more than $70 \%$ by 2020 (SMDRC, 2010). Rural villages continue to be demolished and villagers relocated to newly-built modern residential buildings. As the compensation money for land confiscation was mainly used to buy an apartment in the relocation area (Sze, 2015), many affected peasants are caught in the plight of no land to farm and no post in which to work. During our field survey, we came across a vast area of idle land covering by reeds near the Yu-An Community, in which the majority of former farmers were resettled. We also found some people were cultivating the land (Figure 6). A female told us:

I am living in that building (pointing to a multi-storey residential building behind). Our farm lands have been bought by the government and all villagers ware moved in the Yu-An Community. Since I do not have a job and have nothing else to do, and I found this land has been vacant for a long time, I am thinking to grow some vegetables so we do not need to buy from the market ${ }^{\text {xiii. }}$

The land is a planned construction site for the International Forum Business District (Figures 4 \& 5 ), and the words of this former farmer show the dilemmas of the relocated peasants on Chongming. Even if the Eco-island plan was successfully implemented, there may be a mismatch 
between the proposed industries - focusing on high-tech and data management- and the skills and knowledge of local residents (Cai, 2016). This could cause severe financial difficulties for local people and social stability concerns. Meanwhile, the environmental consequences also cannot be ignored. Rehousing of villagers takes them from their local environment with a consequent loss of their land management knowledge and practices, which will reduce the availability of an alternative expertise to challenge external, professional notions of a good environment (see above) so hastening further change.

Figure 6. Residents in Chenjia Town cultivated temporarily idle construction land for growing vegetables

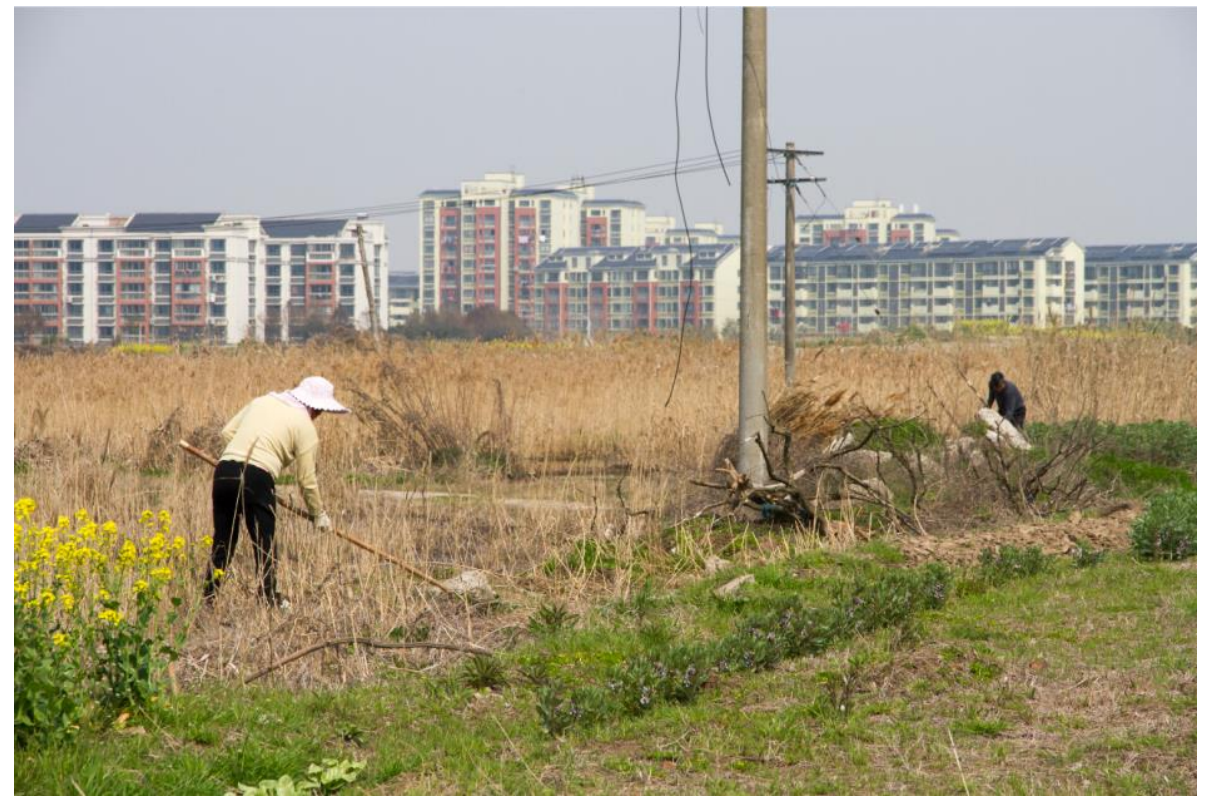

Source: Authors.

While villages were removed, gated communities of opulent villas and high-rise modern residences have mushroomed along the shore and in the central development area of Chenjia Town and Chengqiao Town. Besides a small portion of relocated villagers, most of the homebuyers are from outside of Chongming who have either made an investment or a holiday property purchase. In contrast to the struggling rural villages and residents who remain hidden from public debates, an elite group seems to arouse more attention on the Eco-Island development. Rather like the previous Dongtan eco-city approach the emphasis is on so-called "technological fixes" - using engineering or technology and infrastructure constructions - to create attractive residential locations for domestic and international elites, and this appears to matter more than a concern for residents social well-being (Chang and Sheppard, 2013). This skewed approach to social issues can also be seen in the opening of the tunnel-bridge, which stretches to the planned key development zone of Chenjia Town in the east of the Island where most of the real-estate projects are located, and consequently accentuates the marginalization of the western old town area where most of the residents live. As the urban-rural income gap in 
Chongming is continuously expanding (Chongming Statistics Bureau, 2017), the social injustice of eco-island construction is increasingly striking.

Meanwhile, although public participation and social assessment were written into the policy and plan of the Eco-Island's development (e.g., SMDRC, 2010), they remain underdeveloped. During the development process, planners and bureaucrats admit that it was unclear to them as to how to effectively apply public participation in eco-development, especially in the policy-making and planning-design process. As one local planner explained:

In the current planning and governance system, it is very difficult and impractical to involve the masses in the planning process. Most of the local people are undereducated and only concerned with issues that are directly related to them. So normally they would be actively engaged in the preliminary stage when we are dissecting the local context and identifying the problems, but they would rarely participate in the decision-making process. ${ }^{\text {xiv }}$

However, as the earlier section (see 4.1) shows, local people are knowledgeable about the Island's ecology and resources, as they are the most dependent upon and attached strongly to the environment. Nevertheless, these local communities and users tend to have enormous difficulties in finding a voice (Brogden and Greenberg, 2003). As there are no specific or detailed measures proposed in the policy and plan to effectively involve the public, the impression here is that lurking behind the rhetoric of the Eco-Island planning and policy there is an attempt to reach social cohesion merely at the symbolic level. It is evident from the analysis in this section that the contemporary Eco-Island development has counterproductive effects on social sustainability as it accentuates local people's economic disadvantage and perceptions of social injustice.

\subsection{A Planned Yet Ambiguous Future}

In May 2018, Shanghai Municipal Govenrment approved and issued the "Master Plan and General Land-use Plan of Chongming District of Shanghai, 2017-2035" (Shanghai Municipal Government, 2018). Compared with earlier planning documents there are significant changes in content as it highlights four new development strategies, namely: 1) sticking to the environmental bottom line; 2) vigorously implementing the "Plus Eco" strategy; 3) prudently proceeding with the "Eco plus" strategy; and 4) practically shifting towards "ecological living and production". Perhaps the most significant transformation compared to previous plans is shown in the heavy emphasis placed on ecological protection and development and the weakening of the "Eco plus" strategy, which suggests the Eco-Island development is shifting from an economyoriented path towards a more ecology-centric one. There is, though, an important note of caution. A more eco-centric development strategy is not being formulated for positive reasons so as to move towards new environmental relationships but rather for negative ones because of uncertainty over future development. As a planner who is involved in drafting the plan explained:

Over a decade's development of the Eco-Island, little economic progress has been made under the previous "Eco plus" strategy, whilst the construction activities have 
significantly changed the fabric and landscape of this rural island. As the local and municipal government is still struggling in identifying alternative development pathway that can improve the economy without sacrificing the nature, it is a cautious action to emphasize environmental protection in the current stage. Besides, it is in line with President Xi's new instruction of the development of the Yangtze River Economic Zone to "stick with protection and forbid large-scale development" (gong zhua da bao hu, bu gao da kai fa) ${ }^{x v}$.

So, what can we learn from the 2018 Master Plan of Chongming? There is a recognition of the problems of EM-guided development. The new plan admits that the original ideas of centralized settlements and splitting and reducing villages and towns was inappropriate for ecological development on the Island, and it proposes a shift from the city/town to the whole region, with particular attention paid to ecological and rural areas. As such, the large-scale and big block construction of the original key urban development areas - especially Chenjia Town and Chengqiao Town - are to see their land allocated for construction reduced. In addition, while the plan sticks to the development of high-tech and smart industries in the new towns, it also proposes to construct eight characteristic towns and a number of characteristic villages to promote eco-tourism industries. This action may help to invigorate the local economy and provide diversification in employment opportunities.

Besides the transformation of the planning and development ideas, this Plan also sets up higher demands and more stringent regulation on environmental preservation and construction, as ecological indicators are raised to a new level (for instance, the forest coverage rate is targeted to reach $35 \%$ in 2035 and the natural wetland retention rate is set to reach $43 \%$ ). There is little doubt that, given current thinking, the forest rates on the Island will grow and large-scale urbanization will be at least temporarily suppressed. However, concerns remain. For example, the detailed planning and implementation methods may be as exclusive as before. Questions can also be raised, such as how do policy-makers and practitioners define "nature" and "eco" versus human-made ecological development on Chongming Island? For whom is the Eco-Island to be built? Does a more ecological-centric planning imply a relative neglect of economic and social development and if so, how can sustainability be achieved on Chongming Island?

\section{Conclusion}

Our journey through the planning and development of Chongming Eco-Island has emphasized the problematic nature of state-led, EM-guided eco-development. We have shown that Chongming Eco-island's planning ideology, on-the-ground practices, and its evolution over time reflect the specific contexts of China's socio-political climate and the unique features of Chinese eco-development practices - marked by a strong state, employment of EM methods that are measured by pre-set indicators and limited civil society participation. Firstly, the strong executive power and capacity of the local state is demonstrated through the strict enforcement and swift execution of policies and plans. Secondly, guided by EM principles, measures employed to construct the Eco-Island are led by explicit indicator systems and steered by "technological fixes". To meet quantifiable targets, local cadres adopt a traditional centralized planning and 
development approach. This resulted in simplistic and engineering measures to manage nature, which has negligible appreciation of the local cultural and environmental context. A neat and ordered landscape has been built that contrasts with the more traditional and informal island environment. For longstanding island residents, the new landscape has harmed the local biophysical ecology and communities that they valued so highly. Thirdly, a significant problem identified in the Chongming Eco-Island concerns an almost complete absence of local-level civic participation in the policy-making and planning process. It is local communities, who often are both the most dependent upon and the most knowledgeable about the local environment and its resource. These are the very same people who have the greatest difficulty having their voice heard, and they have been largely left out of the Eco-Island planning and development.

A critical evaluation of the Chongming Eco-Island has also shown that the promises of EM (i.e. constructing a benign ecological environment, boosting the local economy through green industries, achieving win-win sustainable socio-economic outcomes with environmental development) have not been fulfilled. On the contrary, guided by these promises and the assumptions on which they are based, the Eco-Island development generates unintended and adverse results for the local community and the environment (e.g. natural environmental destruction, economic stagnation, and exacerbating social problems). In contesting the current EM thinking and development, we argue that political ecology provides a fruitful counter narrative with which to assess the current and future prospects of Chongming Eco-Island. With its focus on the interplay between people, place and environment, political ecology gives voices to local people, and thus presents a detailed and on-the-ground picture of the eco-development effects that might never be shown in official reports. The framework could be equally well applied to other eco-developments in China.

Can political ecology do more than provide a critical commentary on development? It is difficult to imagine policy makers wholeheartedly embracing the insights derived from a political ecology of Chongming Island (or from that of other studies). Nevertheless, political ecology may, over time, inform policy. This is because while credible alternative narratives can be maintained environmentally unsympathetic, developments will continue to be questioned. Despite the topdown approach to policy making and delivery and the reluctance to listen to local voices there is considerable learning that can take place within Chinese government on the nature of development, as for example, shown by the halting of development on the Island following a visit by a senior political figure (see 4.2 above). Moreover, the silo-based nature of much Chinese policy making means that there is an ongoing search for new ideas and approaches to gain an administrative competitive advantage (as is well illustrated by the rapid adoption of new development opportunities afforded by titles such as eco-city, low carbon city and sponge city).

By integrating a multiscale analysis, we can unravel Shanghai city's intention in shaping the socalled eco-development on Chongming. The city too is working at a multi-scale level to manage its own policy tensions. National policy demands that cities pay more attention to green land. Working across the whole spatial planning area, including Chongming, allows the city government to meet this policy goal. Protecting green land on Chongming enables the city to offset this against further land intensification in its central area. 
Awareness of the deep and complex ways in which the dynamics of unequal social and political power affect ecological or urban systems informs the dual commitment of political ecology to both understanding and action (Paulson and Gezon, 2005). In our study, we highlight three key issues for political ecology to engage with. Firstly, although local spaces clearly matter they need to be contextualized within a multi-scalar approach that reveals the broader regional, national and even global dynamics' that influence local environmental changes. A multi-scalar perspective does not marginalize local places but rather, as we have shown, seeks their simultaneous recognition; places are not merely passive recipients of external forces but actively seeking to shape them. Second, in emphasizing the ways in which power plays out in Chongming, we have demonstrated how technocratic, state informed perspectives matter because they play such a key role in shaping the context in which debate and the variety of environmental practices take place. This allows us to keep the political and the ecological firmly aligned. Third, the development of an ecologically, socially and economically sustainable society involves complex systems that require collaboration and knowledge sharing between disputing stakeholders. In Chongming Eco-Island, the lack of communication between policy makers, planners, indigenous people, and environmental activists' results in vastly divergent attitudes and opinions towards current development practices. Here, though, lies the challenge. Political ecology points to the limited power of marginal groups. This tends to foreclose discussion of alternative futures because the power to realize alternative development trajectories lies in the hands of those who already have power. Consultation or participation exercises are likely to simply reproduce existing power relationships and thus whose knowledge is regarded as legitimate. There, therefore, needs to be more attention paid to the extent to which local people can create and maintain their own political space in which they seek to shape their future. In our work on Chongming Eco-Island, we have made a start by showing how local residents can provide critiques of current development that can then be the basis of imagining alternative ecological futures. At a time when policy on the future of Chongming Eco-Island is in a state of flux, then alternative visions that can play to external policy agendas and coalitions may have some hope of being at least partially realized. This in turn suggests that political ecology work needs to be prepared for long term engagement with communities but also the wider set of actors who are seeking to shape that community. 


\section{References}

Arup 2008. Fact Sheet For Dongtan Eco-City, London Arup Press Office

Barca, S. \& Bridge, G. 2015. Industrialization And Environmental Change. In: Perreault, T., Bridge, G. \& Mccarthy, J. (Eds.) The Routledge Handbook Of Political Ecology. London And New York: Routledge Taylor \& Francis.

Brogden, M. J. \& Greenberg, J. B. 2003. The Fight For The West: A Political Ecology Of Land Use Conflicts In Arizona. Human Organization, 62, 289-298.

Brown, C. J. \& Purcell, M. 2005. There's Nothing Inherent About Scale: Political Ecology, The Local Trap, And The Politics Of Development In The Brazilian Amazon. Geoforum, 36, 607-624.

Bryant, R. L. 1998. Power, Knowledge And Political Ecology In The Third World: A Review. Progress In Physical Geography, 22, 79-94.

Bryant, R. L. and Jarosz, L. 2004. Editorial: Ethics in Political Ecology: A special issue of Political Geography: Introduction: thinking about ethics in political ecology. Political Geography. 23 (7), 807-812.

Bryant, R. L. \& Bailey, S. 1997. Third World Political Ecology, London, Routledge.

Bryant, R. L. (Ed.). (2015). The international handbook of political ecology. Edward Elgar Publishing.

Cai, Y. 2016. Suggestions on Perfecting Chongming's Ecological Compensation Mechanism [关于完善崇 明生态补偿机制的建议]. Chongming United Front Work Department. Available at: http://www.shtzb.org.cn/node2124/node2143/node2194/u1ai1844113.html (accessed on August 10, 2017).

Caprotti, F. 2014a. Critical Research On Eco-Cities? A Walk Through The Sino-Singapore Tianjin Eco-City, China. Cities, 36, 10-17.

Caprotti, F. 2014b. Eco-Urbanism And The Eco-City, Or, Denying The Right To The City? Antipode, 46, 1285-1303.

Caprotti, F., Springer, C. \& Harmer, N. 2015. 'Eco' For Whom? Envisioning Eco-Urbanism In The SinoSingapore Tianjin Eco-City, China. International Journal Of Urban And Regional Research, 39, 495-517.

Caprotti, F. and Gong, Z. 2017. Social sustainability and residents' experiences in a new chinese eco-city. Habitat International, 61: 45-54.

Chang, I. C. C. \& Sheppard, E. 2013. China's Eco-Cities As Variegated Urban Sustainability: Dongtan EcoCity And Chongming Eco-Island. Journal Of Urban Technology, 20, 57-75.

Cheng, H. \& Hu, Y. 2010. Planning For Sustainability In China's Urban Development: Status And Challenges For Dongtan Eco-City Project. Jounal Of Environmental Monitoring 12, 119-26.

China Centre for Modernisation Research (2007) China Modernization Report 2007: Study of Ecological Modernization (Beijing: Beijing University Press) (in Chinese).

China Daily, 2018. China's first urban air quality analysis report released [我国首份城市空气质量分析 报告发布]. Avaiable at: http://top.chinadaily.com.cn/2018-07/06/content_36524472.htm (accessed on September 27, 2018). 
Chongming County Govnerment, 2016. “ECO+" as the development engine of Chongming ["生态十"成为 崇明发展重要引擎]. [Online], Available at: http://www.shanghai.gov.cn/nw2/nw2314/nw2315/nw15343/u21aw1148417.html (accessed on August 26, 2017).

Chongming County Government, 2017. The Notice of Issuing "The Thirteenth Five-year Plan of Chongming County Ageging Programme Development” [崇明县人民政府关于印发《崇明县老 龄事业发展“十三五”规划》的通知. [2017]1. Available at: http://www.cmx.gov.cn/cm website/html/DefaultSite/shcm xxgk zfwj xzfwj 2017/2017-0125/Detail 132368.htm (accessed on August 29, 2017).

Chongming Finance, 2015. Report on the implementation of the budget of Chongming County in 2014 and the budget in the first half of 2015 [关于崇明县 2014 年县本级决算及 2015 年上半年预算 执行情况的报告]. Availbale at: http://czj.shcm.gov.cn/new cmcz czsj czyjsqk czyjsbg/201510-14/Detail 530491.htm (accessed on September 1, 2017).

Chongming Statistics Bureau, 2017. Statistical Communique of National Economic and Social Development in Chongming District in 2016 [2016 年崇明区国民经济和社会发展统计公报]. Available at: http://cmtj.shcm.gov.cn/new cmtji tjsj tjnj/List/index.htm (accessed on August 19, 2017).

Chongming Statistical Society, 2017. A Study on the Chongming Eco-Islands Construction and the Income Gap between Urban and Rural Areas [崇明生态岛建设与城乡收入差距问题研究]. Available at: http://cmtj.shcm.gov.cn/new cmtji tjxh Iwxd/2014-05-06/Detail 203999.htm (accessed on August 10, 2017).

Christoff, P., 1996. Ecological modernisation, ecological modernities, Environmental Politics, 5(3), 476-500.

De Jong, M., Joss, S., Schraven, D., Zhan, C. \& Weijnen, M. 2015. Sustainable-Smart-Resilient-Low Carbon-Eco-Knowledge Cities; Making Sense Of A Multitude Of Concepts Promoting Sustainable Urbanization. Journal Of Cleaner Production, 109, 25-38.

De Jong, M., Wang, D. \& Yu, C. 2013. Exploring The Relevance Of The Eco-City Concept In China: The Case Of Shenzhen Sino-Dutch Low Carbon City. Journal Of Urban Technology, 20, 95-113.

Den Hartog, H., Sengers, F., Xu, Y., Xie, L., Jiang, P., and de Jong, M., 2018, Low-carbon promises and realities: Lessons from three socio-technical experiments in Shanghai. Journal of Cleaner Production, 181: 692-702.

Fisher, D., R. \& Freudenburg, W., R. 2001. Ecological Modernization And Its Critics: Assessing The Past And Looking Toward The Future. Society \& Natural Resources, 14, 701-709.

Forsyth, T. 2004. Industrial pollution and social movements in Thailand. In Peet, R. and Watts, M. (Ed.) Liberation ecologies: environment, development, social movements. London, UK : Routledge, pp. 422-438.

Flynn, A., Yu, L., Feindt, P., and Chen, C. 2016. Eco-cities, governance and sustainable lifestyles: The case of the Sino-Singapore Tianjin Eco-City. Habitat International. 53: 78-86.

Ge \& Zhang, 2016. Transforming from County to District - how to guard the future of Chongming. [崇明 区来了，拿什么守护她的未来]. The Paper, 27 July 2016 [online]. Available at: https://www.thepaper.cn/newsDetail_forward_1504752 (accessed on 20 December, 2018). 
Gouldson, A. \& Murphy, J. 1996. Ecological Modernization And The European Union. Geoforum, 27, 1121.

Grydeh J, A. \& Kelman, I. 2016. Island Smart Eco-Cities: Innovation, Secessionary Enclaves, And The Selling Of Sustainability. Urban Island Studies, 2, Pp. 1-24.

Hajer, M.A., 1996. The Politics of Environmental Discourse: Ecological Modernization and the Policy Process. Oxford University Press, New York.

Harris, L. M. 2017. Political ecologies of the state: Recent interventions and questions going forward. Political Geography, 58, 90-92.

Head, P. R. \& Lawrence, J. G. Urban Development To Combat Climate Change: Dongtan Eco-City And Risk Management Strategies. In: Wood, A., Ed. Ctbuh 8th World Congress, 2008 Dubai, Uae. Council On Tall Buildings And Urban Habitat, 244-251.

Hodson, M. \& Marvin, S. 2010. Urbanism In The Anthropocene: Ecological Urbanism Or Premium Ecological Enclaves? City, 14, 298-313.

Horowitz, L. S. 2015. Local environmental knowledge. In: Bryant, R. L. (Ed.) International Handbook Of Political Ecology Cheltenham, Uk · Northampton, Ma, Usa: Edward Elgar.

Hult, A. 2013. Swedish Production Of Sustainable Urban Imaginaries In China. Journal Of Urban Technology, 20, 77-94.

Hult, A. 2015. The Circulation Of Swedish Urban Sustainability Practices: To China And Back. Environment And Planning A, 47, 537-553.

Hung, L. \& Sheu, J. 2010. The Political Ecology Of A Rual-Urban Interface: Resources, Places And Local Attitudes Toward Guandu Nature Park [交界帶的政治生態學一居民對於關渡自然公園作為 「資源」與「地方」的看法]. Journal Of Geographical Science [地理學報], 60, 1 - 22.

Joss, S., Cowley, R. \& Tomozeiu, D. 2013. Towards The 'Ubiquitous Eco-City': An Analysis Of The Internationalisation Of Eco-City Policy And Practice. Urban Research \& Practice, 6, 54-74.

Joss, S. \& Molella, A. P. 2013. The Eco-City As Urban Technology: Perspectives On Caofeidian International Eco-City (China). Journal Of Urban Technology, 20, 115-137.

Joss, S., Tomozeiu, D. \& Cowley, R. 2011. Eco-Cities - A Global Survey 2011. University Of Westminster.

Keil, R. 2003. Urban Political Ecology 1. Urban Geography, 24, 723 - 738.

Keil, R. \& Desfor, G. 2003. Ecological Modernisation In Los Angeles And Toronto. Local Environment, 8, 27-44.

Krueger, R. \& Gibbs, D. 2007. The Sustainable Development Paradox: Urban Political Economy In The United States And Europe, New York, Guilford Press.

Lang, G. \& Xu, Y. 2013. Anti-incinerator campaigns and the evolution of protest politics in China. Environmental Politics, 22, 832-848.

Leff, E. 2015. The Power-Full Distribution Of Knowledge In Political Ecology: A View From The South. In: Perreault, T., Bridge, G. \& Mccarthy, J. (Eds.) The Routledge Handbook Of Political Ecology. London And New York Routledge Taylor \& Francis.

Liu, Y., Dijst, M., Geertman, S. \& Cui, C. 2017. Social Sustainability In An Ageing Chinese Society: Towards An Integrative Conceptual Framework. Sustainability (2071-1050), 9, 1-15. 
Ma, X., De Jong, M. \& Den Hartog, H. 2017. Assessing the implementation of the Chongming Eco Island policy: What a broad planning evaluation framework tells more than technocratic indicator systems. Journal of Cleaner Production, 172: 872-886

MEP (Ministry of Environmental Protectioon of the People's Republic of China), 2002. Decision on naming the second batch of the National Ecological Demonstration Zone and commending outstanding individuals and institutions [关于命名第二批国家级生态示范区及表彰先进的决 定]. Available at: http://www.mep.gov.cn/gkml/zj/wj/200910/t20091022 172084.htm (accessed on August 8, 2017).

Mol, A. P. J., 2001. Globalization and Environmental Reform: the Ecological Modernization of the Global Economy. MIT Press, Cambridge (Ma).

Mol, A. P. J., Spaargaren, G. \& Sonnenfeld, D. 2009. Ecological Modernisation: Three Decades Of Policy, Practice And Theoretical Reflection. In: Mol, A. P. J., Sonnenfeld, D. A. \& Spaargaren, G. (Eds.) The Ecological Modernisation Reader. Environmental Reform In Theory And Practice. London/New York: Routledge

Muldavin, J. 2013. From Rural Transformation To Global Integration: Comparative Analyses Of The Environmental Dimensions Of China's Rise. Eurasian Geography And Economics, 54, 259-279.

Muldavin, J., 2015. Using Cities to Control the Countryside: An Alternative Assessment of the China National Human Development Report 2013. Development and Change 46(4): 993-1009.

Neo, H. \& Pow, C. P. 2015. Eco-Cities And The Promise Of Socio-Environmental Justice. In: Bryant, R. L. (Ed.) The International Handbook Of Political Ecology. Edward Elgar Pub.

Neumann, R. P. 2005. Making Political Ecology London, Hodder Arnold.

Paulson, S. \& Gezon, L. L. 2005. Political Ecology Across Spaces, Scales, and Social Groups New Brunswick, Rutgers University Press.

Peet, R., Robbins, P. \& Watts, M. 2011. Global Political Ecology Abingdon, Uk, Routledge

Pepper, D. 1998. Sustainable Development And Ecological Modernization: A Radical Homocentric Perspective. Sustainable Development 6, 1-7.

Perreault, T., Bridge, G. \& Mccarthy, J., 2005 (Eds.) The Routledge Handbook of Political Ecology. London And New York: Routledge Taylor \& Francis

Pow, C. P. \& Neo, H. 2013. Seeing Red Over Green: Contesting Urban Sustainabilities In China. Urban Studies, 50, 2256-2274.

Pow, C. P. 2018. Building a Harmonious Society through Greening: Ecological Civilization and Aesthetic Governmentality in China, Annals of the American Association of Geographers, 108:3, 864-883.

Rapoport, E. \& Hult, A. 2017. The Travelling Business Of Sustainable Urbanism: International Consultants As Norm-Setters. Environment And Planning A, 49, 1779-1796.

Robbins, P. 2003. Political Ecology in Political Geography. Political Geography, 22, 641-645.

Robbins, P. 2012. Political Ecology, 2nd edn, Oxford: Wiley-Blackwell.

Robbins, P. \& Sharp, J. 2003. The Lawn-Chemical Economy And Its Discontents. Antipode, 35, 955-979. 
Shanghai Municipal Government, 2006. Overall Plan for Chongming Three Islands. Available at: http://www.shsz.org.cn/book/shownews.asp?num=szzz-2006929154014 (accessed August 7, 2017).

Shanghai Municipal Government, 2010. The Revised General Plan of Chenjia Town in Shanghai Chongming (2009-2020) [上海崇明陈家镇城镇总体规划修改 (2009-2020)]. Available at: http://www.shgtj.gov.cn/ghsp/ghsp/cm/201703/t20170301_712808.html (accessed on August 9, 2017).

Shanghai Municipal Government, 2016a. Chongming County's upgrade to Chongming District Passed by Shanghai Municipal People's Congress. Available at: http://www.shanghai.gov.cn/nw2/nw2314/nw2315/nw4411/u21aw1150217.html (accessed on August 8, 2017).

Shanghai Municipal Government, 2016b. Notice of the Municipal Government on Printing and Distributing the 13th Five - Year Plan of Chongming World - class Ecological Island Development [市政府关于印发《崇明世界级生态岛发展“十三五”规划》的通知]. Available at: http://www.shanghai.gov.cn/nw2/nw2314/nw2319/nw12344/u26aw50776.html (accessed on August 19, 2017).

Shanghai Municipal Government, 2018. Chongming District Master Plan \& Land Utilization Master Plan (2017-2035) [崇明区总体规划暨土地利用总体规划（2017-2035）]. Available at: http://www.cmx.gov.cn/UpLoadPath/2018/5/30/b1d3c678-6619-4f41-b6a0-7e72daa4c412.pdf (accessed on 24 June, 2018).

SMDRC (Shanghai Municipal Development \& Reform Commission), 2010. Chongming Eco-Islands Construction Outline (2010-2020) [崇明生态岛建设纲要（2010-2020 年）（摘要）]. Available at: http://www.shdrc.gov.cn/gk/xxgkml/ggig/zxgg/17344.htm (accessed on August 9, 2017).

State Council, 2005. State Council's approvement on Shanghai's administrative divisions adjustment of Baoshan District and Chongming County [国务院关于同意上海市调整宝山区和崇明县行政区 划的批复]. Available at: http://www.gov.cn/gongbao/content/2005/content_64278.htm (accessed on September 25, 2018).

State Council, 2018. Notice of the State Council on Printing and Distributing the Three-Year Action Plan for Winning the Blue Sky Defence War [国务院关于印发打赢蓝天保卫战三年行动计划的通 知]. Available at: http://www.gov.cn/zhengce/content/2018-07/03/content_5303158.htm (accessed on September 27, 2018)

SUPDI (Shanghai Urban Planning and Design Institute). 2005. Overall Plan for Chongming Three Islands (2005-2020).

Swyngedouw, E. 1997. Power, Nature, And The City. The Conquest Of Water And The Political Ecology Of Urbanization In Guayaquil, Ecuador: 1880-1990. Environment And Planning A, 29, 311-332.

Swyngedouw, E. 2004. Scaled Geographies: Nature, Place, And The Politics Of Scale. In: Mcmaster, R. \& Sheppard, E. (Eds.) Scale And Geographic Inquiry: Nature, Society And Method. Blackwell Publishers. Oxford And Cambridge, Mass: Blackwell Publishers.

Sze, J. 2015. Fantasy Islands: Chinese Dreams And Ecological Fears In An Age Of Climate Crisis. University Of California Press.

Tan-Mullins, M., Cheshmehzangi, A., Chien, S. and Xie, L. 2017a. Smart-Eco Cities in China: Trends and City Profiles 2016. Exeter: University of Exeter (SMART-ECO Project). ISBN: 978-0-9955574-2-0. 
Tan-Mullins, M., Urban, F. \& Mang, G. 2017b. Evaluating The Behaviour Of Chinese Stakeholders Engaged In Large Hydropower Projects In Asia And Africa. The China Quarterly, 230, 464-488.

Tilt, B. 2007. The Political Ecology of Pollution Enforcement in China: A Case from Sichuan's RuralIndustrial Sector. The China Quarterly, 192, 915-932

Unep 2014. Chongming Eco-Islands International Evaluatuion Report. United Nations Environment Programme.

Xie, L. 2015. Political Participation And Environmental Movements In China. In: Bryant, R. L. (Ed.) International Handbook Of Political Ecology. Cheltenham, Uk · Northampton, Ma, Usa: Edward Elgar.

Yeh, E. T. 2009. Greening Western China: A Critical View. Geoforum, 40, 884-894.

Yeh, E. T. 2015. Political Ecology In And Of China. In: Bryant, R. L. (Ed.) The International Handbook Of Political Ecology. Cheltenham, Uk · Northampton, Ma, Usa: Edward Elgar Publishing

Yu, L. 2012. '对中国生态城现状问题的批判性分析'[Critical Analysis Of Problems In Chinese Eco-City Development]. 新建筑[New Architecture], 4, 25-6.

Yu, L. 2014. Low Carbon Eco-City: New Approach For Chinese Urbanisation. Habitat International, 44, 102-110.

Zhang, L., Mol, A.P.J., Sonnenfeld, D., 2007. The interpretation of ecological modernization in china. Environ. Politics 16 (4), 659-668.

Zhou, Y. 2015. State power and environmental initiatives in China: Analyzing China's green building program through an ecological modernization perspective. Geoforum. 61, pp. 1-12. 


\section{Notes}

' Interview with a local planning expert who is involved in the planning of Chongming Eco-island on April 13, 2017 in English.

ii Interview with a local planning expert on July 9, 2017 in Mandarin, translated by Xie, L.

iii Interviews with a few tourists on the island and two immigrant eco-farmers during November 25-27, 2016 in Mandarin, translated by Xie, L.

iv As urban sewage treatment rate is the obligatory target in the plan while the rural sewage treatment rate is an anticipated target, rural sewage treatment receives much less attention in the eco-island plan.

$\checkmark$ Interview with a local resident, also an environmental activist on February 13, 2017 in Mandarin, translated by Xie, L.

vi Interview with a local "river cleaner" who was hired by the Chongming Water Authority from 2007 to 2009 to conduct river cleaning and maintenance on September 12, 2018 in Mandarin, translated by Xie, L.

vii Trees planted on the island are mostly Metasequoia glyptostroboide, which is a fast-growing, deciduous tree, with a good adaptation for a diversity of climate and site conditions. Due to its wind-tolerance character, it is deemed as the most suitable tree species for afforestation on Chongming (interview with a local planning expert on August 30, 2017 in Mandarin, translated by Xie, L.).

viii Interview with a local resident, also an environmental activist on February 13, 2017 in Mandarin, translated by Xie, L.

ix Interview with a local farmer on February 13, 2017 in Mandarin, translated by Xie, L.

${ }^{x}$ Focus group meeting on March 31, 2018 in Mandarin, translated by Xie, L.

xi Interview with a local government official on August 30, 2017 in Mandarin, translated by Xie, L.

xii Interview with a local planner on August 30, 2017 in Mandarin, translated by Xie, L.

xiii Talk with a local resident on March 23, 2018 in Mandarin, translated by Xie, L.

xiv Interview with a local planner on August 30, 2017 in Mandarin, translated by Xie, L.

${ }^{x v}$ Interview with a local planning expert on July 9, 2017 in Mandarin, translated by Xie, L. 